\title{
NOTA SOBRE MARCEL MAUSS E O ENSAIO SOBRE A DÁDIVA
}

\author{
Marcos Lanna \\ Universidade Federal do Paraná
}

\begin{abstract}
RESUMO
Este artigo analisa a obra clássica de M. Mauss, Ensaio sobre a dádiva, à luz de desenvolvimentos recentes da Antropologia. Salienta como contribuição de Mauss o entendimento da dimensão política da troca de dádivas, assim como a sugestão de sua universalidade, posteriormente demonstrada por Lévi-Strauss, constituir-se em princípio formal-abstrato, e não num fato empírico-concreto. A partir desse princípio, avalia a tese segundo a qual a dádiva é fundamento de toda sociabilidade e comunicação humanas, assim como sua presença e sua diferente institucionalização em várias sociedades analisadas por Mauss, capitalistas e nãocapitalistas.
\end{abstract}

PALAVRAS-CHAVE: Marcel Mauss; teoria da troca; reciprocidade; hierarquia.

\section{SOBRE MARCEL MAUSS}

O Ensaio sobre a dádiva, obra fundamental de Marcel Mauss, é um marco no desenvolvimento da sociologia durkheimiana. Esse desenvolvimento é no sentido de uma Antropologia. Mauss avança, em relação a Durkheim, ao aprofundar uma postura crítica em relação à filosofia, adotando a etnografia, abrindo-se para as sociedades não-ocidentais e assumindo cada vez mais a comparação. Talvez por isso mesmo, a obra de Mauss se caracterize pela dispersão, como ele próprio reconhece ${ }^{1}$. Mauss interessava-se pelas manifestações dos fenômenos humanos em quaisquer tempo e espaço do planeta e sua obra aborda uma "variedade vertiginosa de temas", para usar uma expressão de Gomes Jr. (1999). O Ensaio sobre a dádiva reflete de modo evidente esses aspectos, presentes também em outros trabalhos de Mauss. Inicia-se com menções a questões de

\footnotetext{
1 "Não estou interessado em desenvolver teorias sistemáticas [...] Trabalho somente meus materiais e se, ali ou acolá, aparece uma generalização válida, eu a estabeleço e passo a qualquer outra coisa. Minha preocupação principal não é elaborar um grande esquema geral que cubra todo o campo - tarefa impossível -, mas somente mostrar algumas das dimensões do campo do qual apenas tocamos as margens [...]. Tendo trabalhado assim, minhas teorias são dispersas e não sistemáticas” (apud FOURNIER, 1993, p. 106).
}

língua norueguesa antiga e posteriormente aborda as mais variadas formas de organização social, de grupos e regiões os mais diversos - celtas, Índia, China, Oceania, índios do noroeste americano.

A obra de Mauss tem recebido a mais favorável aceitação por antropólogos contemporâneos das mais diversas inclinações teóricas. Ela presta-se, sem dúvida, a interpretações discrepantes, múltiplas e divergentes, dentro e fora da Antropologia.. A inspiração de Mauss é aceita por sociólogos (de G. Gurvitch a P. Bourdieu, passando pelo grupo que se autodenomina "de vanguarda" do Collège de Sociologie - cf. JAMIN, 1992, p. 457), escritores ou filósofos (R. Callois, G. Battaille, entre outros), historiadores (F. Braudel e a escola dos Annales) ou mestres da Antropologia inglesa (A. R. Radcliffe-Brown, E. E. Evans-Pritchard, R. Firth). A aceitação de Mauss é geral: Guidieri (1984, p. 31) notou que Mauss recebe, de modo bastante freqüente, tratamento "hagiográfico".

Mais recentemente, a Antropologia norteamericana pós Clifford Geertz (seja lá como rotulemos suas diversas correntes interpretativista, pós-moderna, textualista etc.), preza em Mauss, de modo surpreendentemente geral, uma suposta aversão à noção de sistema, "confusão inspirada" e "caráter boêmio" (GOMES JR., 1999). Em The predicament of culture, de 1988, James Clifford aproxima a obra de Mauss do que chama de "etnografia surrealista", notando 
a presença constante de artistas surrealistas em suas aulas.

Seria possível argumentar que um desenvolvimento pleno da obra de Mauss foi feito por três de seus ex-alunos, que vêm a ser os pais fundadores do estruturalismo francês em Antropologia: Georges Dumézil, Claude Lévi-Strauss e Louis Dumont. Mas isso seria assunto para um outro trabalho: importa aqui realizar uma leitura do Ensaio sobre a dádiva. Para tanto, adotarei uma postura oposta à de alguns apologistas contemporâneos de Mauss, como os citados pós-modernistas norte-americanos: não irei correlacionar um espírito não-dogmático com a aversão à noção de sistema ou com o culto a uma "confusão inspirada". Afinal, o próprio Mauss (1983, p. 139) definia-se como um cientista social "positivista".

Mauss pautou sua vida por um esforço para separar vida pessoal - na qual ele incluía suas atividades como militante socialista - e acadêmica: "em Mauss, ciência e política não se confundem" (FOURNIER, 1993, p. 107). Mauss não deixará de publicar, entretanto, em 1924, uma "Apreciação sociológica do bolchevismo" na Revue de Métaphysique et de Morale e em 1925, na Revue Slave, o artigo "Socialismo e bolchevismo". Mauss publica ainda em jornais textos que classifica como "políticos", o primeiro dos quais sendo "L'action socialiste", em Le Mouvement Socialiste de 15 de outubro de 1899. Essa dualidade será discutida no decorrer deste artigo.

O leitor encontrará em Fournier (1993, entre outros) importante análise sobre a biografia e a postura pessoal de Mauss, que tanto marcou seus alunos, como vários deles já comentaram (LÉVISTRAUSS, 1944; DUMONT, 1986). Um interessante contraste poderia ser feito, a este respeito, entre Mauss e o espírito extremamente metódico e rigoroso de Durkheim, já descrito como dogmático por Lévi-Strauss (1944) ou "cartesiano" pelo próprio Mauss (1983, p. 140). Talvez a postura pessoal de cada um explique o sucesso maior que teve Mauss em deixar "discípulos", cultuadores de sua memória, enquanto Durkheim nos deixa como legado menos uma memória que a impessoalidade de "uma obra". Mas, cada qual ao seu modo, sobrinho e tio compartilhavam a mais completa dedicação aos trabalhos da escola sociológica que fundavam.

A contribuição de Mauss se caracteriza ainda, como ele mesmo notou, por um certo "anonimato voluntário" (idem, p. 139) e "auto-sacrifício" (idem, p. 140). Por exemplo, Mauss completou e publicou alguns estudos iniciados por companheiros do grupo que se unia em torno da revista fundada por Durkheim, L'Année Sociologique, precocemente desaparecidos, como Henri Hubert, Robert Hertz (este durante a I Guerra Mundial) e do próprio Durkheim. Após ter recusado um cargo de professor em Bordeaux em 1893, Mauss assume em 1901, em Paris, a cadeira de "História da religião dos povos não-civilizados" da 5 a seção da École Pratique des Hautes Études. Com a morte de Durkheim em 1917, conta com a ajuda de C. Bouglé, G. Davy, P. Fauconnet e M. Halbwachs para retomar a publicação de L'Année Sociologique.

Paralelamente, é intensa sua atividade como militante político. Com Léon Blum, a quem conhece desde a primeira década deste século, é fiel ao socialismo de Jaurés. Mauss e Blum opõemse, no período entre guerras, à criação do Partido Comunista Francês (cf. FOURNIER, 1993, p. 104). Em 1904, Mauss participa da fundação do L'Humanité, tornando-se posteriormente secretário de redação, mas é bastante crítico em relação à revolução bolchevique ${ }^{2}$. Escreve ainda para $L e$ Populaire a partir de 1920 (cf. JAMIN, 1992, p. 456). Simultaneamente, funda em 1925 com L. Lévy-Bruhl e P. Rivet o Institut d'Ethnologie da Universidade de Paris, onde a sua carga de aulas se acumula com a que tinha na École. Quase não tinha tempo para publicar seus próprios trabalhos, mas forma toda a primeira geração de antropólogos de campo franceses (G. Devereux, G. Dieterlen, M. Griaule, A. G. Haudricourt, M. Leiris, A. Métraux, D. Paulme, A. Schaeffner, J. Soustelle, entre outros). Chega ao Collège de France em 1931.

Como foi dito, Mauss (1983, p. 142) reconhece o caráter "descontínuo" de sua obra. A unidade desta deriva de um esforço "para organizar não meramente idéias, mas antes de tudo fatos [...] tomados de civilizações [ainda] não categorizadas" (idem, p. 143). Ou melhor, seu interesse não seria tanto pelos fatos em si, mas por "grupos

\footnotetext{
2 “Como 'sociólogos ingênuos', os bolcheviques acreditaram poder construir uma sociedade 'a golpes de decretos, a golpes de violência'. É um erro, pensa Mauss: 'a violência é estéril em nossas sociedades modernas" (FOURNIER, 1993, p. 111).
} 
geográficos de fatos"; nesta passagem, Mauss cita como exemplo de "grupos geográficos de fatos" os "sistemas religiosos africanos - como [eles] se constituem" (MAUSS, 1983, p. 144). Avança ainda que se trata de um "estudo global sobre a noção de civilização" (idem, p. 151). Mauss parece consciente de que não era isso o que o público francês desejava, pois esse "público é ainda por demais apegado à metodologia sociológica e nossos estudantes e colegas por demais entrincheirados em reflexões filosóficas" (idem, p. 150).

Ao contrário de Durkheim, Mauss diz "não ter sido nunca um militante da sociologia" (idem, p. 142). Por outro lado, não só militava no Partido Socialista Francês, como doava a este parte de suas parcas economias (FOURNIER, 1993). Se Mauss separava sua atividade intelectual de sua militância política, a interpretação que farei aqui do Ensaio sobre a dádiva não deixará de buscar entender essa aparente ruptura. Mas repito que não analisarei a vida pessoal ou a militância política de Mauss; remeto novamente o leitor interessado nestas últimas aos trabalhos de M. Fournier.

\section{A TESE GERAL DO ENSAIO SOBRE $A$ DÁDIVA}

Se Mauss assume a descontinuidade de sua obra, ela também caracteriza o Ensaio sobre a dádiva. Um mesmo parágrafo do Ensaio apresenta comparações entre várias regiões do globo. Publicado no tomo I do L'Année Sociologique (1923-24), um ano após Os argonautas do Pacifico ocidental, neste trabalho Mauss teve de confrontar-se com o fato de, ao contrário de Malinowski, nunca ter feito pesquisa de campo. Mauss não pôde aproveitar uma das principais possibilidades abertas por Malinowski: a realização de pesquisas que buscassem uma maior contextualização dos dados, como propunha, na mesma época, também A.R. Radcliffe-Brown, cujo Andaman islanders data igualmente de 1922. Mauss beneficia-se ainda, no Ensaio, das pesquisas de Franz Boas nos Estados Unidos, que também demonstravam desde o início do século, a importância do trabalho de campo e da contextualização. Boas, Malinowski e Radcliffe-Brown trabalhavam assim contra aquilo que este último denominou "história conjetural". Poder-se-ia mostrar que Mauss não se livrou totalmente desta última. O Ensaio sobre a dádiva arrola uma quantidade impressionante de fatos, que só em um momento posterior seriam melhor contextualizados pelas pesquisas de campo de inúmeros antropólogos, alguns dos quais alunos de Mauss.

Mas há um fio condutor no Ensaio: a noção de "aliança". Como ficará evidente no trabalho de alunos de Mauss, a preocupação com a aliança torna-se uma característica central da Antropologia francesa (DUMONT, 1971). Mauss demonstra no Ensaio como "toda representação é relação - isto é, funda-se sobre a união de uma dualidade de contrários" (JAMIN, 1992, p. 456). Ora, o argumento central do Ensaio é de que a dádiva produz a aliança, tanto as alianças matrimoniais como as políticas (trocas entre chefes ou diferentes camadas sociais), religiosas (como nos sacrifícios, entendidos como um modo de relacionamento com os deuses), econômicas, jurídicas e diplomáticas (incluindo-se aqui as relações pessoais de hospitalidade). Posteriormente, as pesquisas de inúmeros antropólogos revelaram a amplitude - já intuída por Mauss - das noções de dádiva e de aliança. Entre eles, Lévi-Strauss (1949) fez dessas noções o fundamento das estruturas elementares do parentesco; P. Clastres (1978), da sociedade contra o Estado, e, muito modestamente, Lanna (1995) da dívida divina, implícita em relações de compadrio e patronagem no Brasil.

Mas Mauss já definia a dádiva de modo amplo. Ela inclui não só presentes como também visitas, festas, comunhões, esmolas, heranças, um semnúmero de "prestações" enfim - prestações que podem ser "totais" ou "agonísticas" (incluindose, neste último caso, como veremos, o potlatch dos índios do noroeste americano - MAUSS, 1983, p. 147). Creio ser fundamental notar como Mauss entendia até mesmo os tributos como uma forma de dádiva. Esta é uma de suas proposições que aguardam futuros desenvolvimentos.

Voltando à tese principal do Ensaio: nele se postula um entendimento da constituição da vida social por um constante dar-e-receber. Mostra ainda como, universalmente, dar e retribuir são obrigações, mas organizadas de modo particular em cada caso. Daí a importância de entendermos como as trocas são concebidas e praticadas nos diferentes tempos e lugares, de fato que elas podem tomar formas variadas, da retribuição pessoal à redistribuição de tributos. Mauss dedicava especial atenção ao fato de algumas trocas serem prerrogativas de chefias: receber tributo, por exemplo. Essas prerrogativas podem ser socialmente construídas de modo diferente, como privilégios, obrigações etc. A isso Mauss associava o fato de que, freqüentemente, da chefia emanam valores que se 
extendem à sociedade como um todo, generalizando-se (um pouco como Marx mostrara ter a moeda capacidade para generalizar-se como valor capitalista). Como foi posteriormente desenvolvido por P. Clastres (1978), a dádiva de palavras ou objetos é freqüentemente um dever da chefia, em um sentido ontológico: mais que condição necessária da sua existência, são manifestações particulares da chefia que se criam por diferentes formas de troca. Citando o tomo II da Ethnographie de Madagascar de Grandidier, Mauss (1974, p. 66) nos lembra que "os betsimisaraka nos contam que de dois chefes, um distribuía tudo o que estava em sua possessão e o outro não distribuía nada e guardava tudo. Deus deu fortuna ao que era liberal e arruinou o avarento". Veremos a seguir como a chefia se define a partir de uma posição privilegiada em relação às trocas, centralizando-as nos sistemas antigos de redistribuição, como o dos Incas, impérios africanos ou asiáticos, ou no caso de sociedades socialistas.

Mas, evidentemente, o aspecto generativo ou criador de sociabilidade da dádiva não se limita à política. Já a epígrafe do Ensaio exprime uma dialética inerente à dádiva: ao receber alguém estou me fazendo anfitrião, mas também crio, teórica e conceptualmente, a possibilidade de vir a ser hóspede deste que hoje é meu hóspede. A mesma troca que me faz anfitrião, faz-me também um hóspede potencial. Isto ocorre porque "dar e receber" implica não só uma troca material mas também uma troca espiritual, uma comunicação entre almas. É nesse sentido que a Antropologia de Mauss é uma sociologia do símbolo, da comunicação; é ainda nesse sentido ontológico que toda troca pressupõe, em maior ou menor grau, certa alienabilidade. Ao dar, dou sempre algo de mim mesmo. Ao aceitar, o recebedor aceita algo do doador. Ele deixa, ainda que momentaneamente, de ser um outro; a dádiva aproxima-os, torna-os semelhantes. A etnografia da troca dá ainda um novo sentido às etiquetas sociais. Por mais que estas variem, elas sempre reiteram que, para dar algo adequadamente, devo colocar-me um pouco no lugar do outro (por exemplo, de meu hóspede), entender, em maior ou menor grau, como este, recebendo algo de mim, recebe a mim mesmo (como seu anfitrião).

Tão próximo da ideologia da generosidade e do altruísmo, o ato de dar, mostra-nos Mauss, não é um ato desinteressado. Isso não se limita à prática dos "chefes". O ato de dar pode assim se associar em maior ou menor grau a uma ideologia da gene- rosidade, mas não existe a dádiva sem a expectativa de retribuição. O free gift de Malinowski, este sim, é pura ideologia; o altruísmo puro é uma mistificação. Mauss, escrevendo com Hubert o Ensaio sobre a natureza e função do sacrifício, já mostrara, em 1898, que "esta abnegação e essa submissão não deixam de ter um lado egoísta". Para Mauss, a dádiva é um ato simultaneamente espontâneo e obrigatório. O estudo da dádiva permitiria à sociologia a superação relativa de dualidades profundas do pensamento ocidental, entre espontaneidade e obrigatoriedade, entre interesse e altruísmo, egoísmo e solidariedade, entre outras ${ }^{3}$. Este ponto é importante porque a conclusão do Ensaio irá criticar a generalização da noção de interesse individual implícita na sociedade burguesa e no pensamento liberal, que irão opor radicalmente aquilo que a dádiva une.

Um dos representantes do pensamento liberal no Brasil, Delfim Netto (1999), notou recentemente que tal preocupação em propor alternativas à ética do mercado valeu o Prêmio Nobel de Economia de 1998 ao indiano Amartya Kumar $\mathrm{Sen}^{4}$. Talvez até porque conhece "por dentro" uma "civilização da dádiva", como a indiana, pôde Sen reconhecer que o desejo egoísta do lucro não só é incapaz de fundar qualquer sociedade, mas tende, justo ao contrário, a inviabilizá-las. Como Mauss, os estudos de Sen debruçam-se sobre

3 Um dos pareceristas anôminos da Revista de Sociologia e Política lembra haver distinção entre "superar" e "mediar" antinomias, o que me parece rigorosa e filosoficamente correto. Para uma argumentação que busca mostrar que Mauss realmente promoveria uma "superação” das mencionadas dualidades, cf. Caillé (1998). A meu ver, a posição de Mauss, como a de Lévi-Strauss, realmente acena mais para uma "mediação" que para uma "superação" dessas antinomias. Por outro lado, eu proporia que Mauss nos ensina ainda que a "mediação" é a "superação" possível. Esta parece ser a conclusão de Viveiros de Castro (1996) - um autor que acredito representar bem os desenvolvimentos recentes dessa eminente linhagem -, a respeito de outras antinomias, correlatas àquelas que mencionei, como cultura/natureza e razão prática/razão simbólica. Quando uso assim "superação relativa”, eu talvez devesse deixar mais clara minha própria posição, no sentido de que trata-se realmente mais de "mediação" do que de "superação". Para uma análise a respeito da mediação entre as categorias de "sujeito" e "objeto" na obra de C. Lévi-Strauss, cf. Lanna (1999).

4 Digo pensamento liberal, mas evidentemente, foi outra a prática desse que foi um tirano de nossa economia. Como indica outro parecerista da Revista de Sociologia e Política, é "paradoxal” (e tragicamente irônico, eu 
"tragédias distributivas" e recusam fundamentos como a noção de escassez. Entretanto, Sen parece estar muito aquém de Mauss, não chegando nem mesmo a fazer uma crítica ao paradigma utilitarista. Isto é, seus trabalhos revelam uma incorporação da lógica da dádiva pelo pensamento liberal, mais do que o contrário. Já Mauss foi o inspirador de um "Movimento anti-utilitarista nas Ciências Sociais", que publica há mais de uma década importante periódico semestral, La Revue du M.A.U.S.S. . Menciono Sen para mostrar a atualidade do pensamento de Mauss, cuja preocupação com instituições arcaicas jamais significaram a postulação de um retorno nostálgico a um passado pré-moderno. Seu horizonte é o da defesa de um equilíbrio entre o individualismo e a moralidade, por um lado, e o direito da dádiva, por outro. Mauss reconhecia o fato básico de que na modernidade "somos cidadãos e não santos [...]. O socialismo é para Mauss 'um espírito [...] um novo sistema de valores', um 'novo sistema moral de castigos e recompensas"” (FOURNIER, 1993, p. 108).

Finalmente, eu salientaria como fundamental outra contribuição de Mauss, a de que a vida social não é só circulação de bens, mas também de pessoas (mulheres concebidas como dádivas em praticamente todos os sistemas de parentesco

acrescentaria) recuperar aqui o pensamento de um homem que deu "expressivo exemplo de falta de ética" e protagonizou verdadeira "predação do social". Isso, entretanto, revela a força do pensamento liberal, mesmo em tempos de pós-modernidade e mesmo em uma realidade de centralização político e econômica como a brasileira. O mesmo poderia ser dito para R. Campos, que declarou em recente entrevista algo que resume bem uma das teses principais deste meu artigo, a de que a desigualdade política não é exterior à troca: "só tem independência de fato quem não se endivida [...] a autonomia não é uma opção política, mas está subordinada à condição econômica" (apud LUCENA, 1999). Pretendo aqui oferecer uma interpretação maussiana de posições como essa e implicitamente, de um modo mais amplo, do próprio pensamento liberal. Aliás, é impressionante o contraste entre pensamento e prática desses ex-ministros da ditadura militar, o que revela as dificuldades e distorções do pensamento liberal no contexto brasileiro, assim como sua incapacidade para contextualizar-se, na prática, enquanto pensamento liberal (caso típico do que alguns entendem como "idéia fora do lugar"), e, ao modo de Mauss, informar-se pelo social concreto. Nos termos deste, a autonomia desejada por Campos não é nunca plena, sem o seu oposto, a dependência. conhecidos), nomes, palavras, visitas, títulos, festas. Note-se que as trocas não são só materiais: a circulação pode implicar prestações de valores espirituais, assim como maior ou menor alienabilidade do que é trocado. Por exemplo, os sobrenomes na nossa sociedade são pouco alienáveis, circulam ainda menos que os prenomes, mas sua circulação gera considerável valor. Há, entretanto, outras dádivas que devem necessariamente circular muito, para gerar cada vez mais valor, como os objetos kula descritos por Malinowski. A relação entre maior ou menor alienabilidade e criação de valor não é, assim, como veremos, simples e direta.

\section{LENDO A INTRODUÇÃO DO ENSAIO SOBRE A DÁDIVA}

C. Lefort (1979) notou que a questão “o que é uma sociedade" está sempre subentendida em toda a obra de Mauss. Este fala em "contrato" para exprimir a sociabilidade criada pela dádiva. Para Mauss, a noção de contrato seria universal, mas, ao contrário dos contratualistas anglo-saxões, concebe os contratos como não-individuais. Não se trata assim de acordos entre indivíduos racionais mas de regras da organização social primitiva. Nela, "os contratos fazem-se sob a forma de presentes" (MAUSS, 1974, p. 41). Mas se há momentos em que Mauss pensa a troca como um contrato, há outros em que ele, funcionalisticamente, supõe a troca como reforçando realidades pré-existentes, ou "também um meio de fortalecer o contrato" (idem, p. 40). Isso indica que, se seu próprio trabalho permite a superação do funcionalismo e da chamada "razão prática" 5 , há momentos em que ele se contamina por estes procedimentos, os quais critica. Esta passagem inicial da introdução do Ensaio já anuncia como este texto é profundamente "descontínuo".

Para Mauss (1974, p. 41), "este trabalho é um fragmento de estudos mais vastos". A elaboração desse trabalho exigiu o conhecimento de uma grande quantidade de fatos de várias civilizações. Como expressar a universalidade de uma idéia, a importância da troca? Mauss opta por tratar da

\footnotetext{
5 Assumo aqui o entendimento de Sahlins (1976) do que seria a "razão prática", um paradigma das ciências sociais que se caracteriza por reduzir as relações sociais à relações entre meios e fins, à maximização de objetivos ilimitados a partir de recursos escassos.
} 
Polinésia no "Capítulo I", das Ilhas Andaman, no Oceano Índico, Melanésia e do noroeste americano no "Capítulo II", das chamadas sociedades antigas (Roma, Índia, povos germanos) no "Capítulo III" e da Europa moderna na "Conclusão".

As maiores contribuições do Ensaio talvez sejam:

1) mostrar que fatos - incluindo-se aqui tanto a prática da troca como a reflexão sobre ela - das mais diferentes civilizações nos revelam que trocar é mesclar almas, permitindo a comunicação entre os homens, a inter-subjetividade, a sociabilidade. A Antropologia é o estudo desta comunicação e das regras que a estabelecem;

2) essas regras manifestam-se simultaneamente na moral, na literatura, no direito, na religião, na economia, na política, na organização do parentesco e na estética de uma sociedade qualquer. Podemos isolar o aspecto econômico de uma troca, mas ela implica sempre também um aspecto religioso (que se evidencia nos sacrifícios, nas dádivas de palavras das rezas etc.), político (que se evidencia nas trocas mal-sucedidas - que redundam em guerra -, na troca de violência ou ainda no desequilíbrio entre o que é trocado $^{6}$ e na assimetria temporal implícita em qualquer redistribuição - cf. BOURDIEU, 1996), ou mesmo estético (a confecção dos objetos, o modo de oferecimento etc.). A troca é assim um fato social "total". Ela o é ainda no sentido de manifestar-se

\footnotetext{
6 A última estrofe da epígrafe do Ensaio (de número 145), por exemplo, indica que nunca se dá demais a um superior, seja ele chefe ou o deus, pois o ato de dar gera sempre certa superioridade, política e religiosa. A epígrafe indica também que o fato de não se retribuir adequadamente, a avareza (que pode ser entendida como uma manipulação da troca), gera o medo. Sugere-se assim algo que será repetidamente indicado por Mauss: basta haver uma prestação unilateral, um oferecimento e uma aceitação para haver dádiva e essa prestação unilateral para se gerar valor; isto é, uma ética impõe-se mesmo àqueles que não a retribuem, ainda que isso ocorra diferentemente em cada caso específico. Isso é importante porque, a meu ver (LANNA, 1996), quando se fala em dádiva, não é de troca que se fala; trata-se de uma prestação unilateral, na qual há simultaneamente o ato de dar (por um sujeito $A$ ) e o de "receber" (por um outro sujeito $B$ ).
}

historicamente em cada indivíduo ${ }^{7}$;

3) as trocas são simultaneamente voluntárias e obrigatórias, interessadas e desinteressadas, como eu dizia, mas também simultaneamente úteis e simbólicas. Mauss enfraquece a dicotomia símbolo/morfologia presente na obra de Durkheim. Desde Formas primitivas de classificação, publicado em $1903 \mathrm{e}$ escrito em parceria com este último, Mauss já nos mostrava como a morfologia social também é um fato simbólico;

4) Mauss propõe um método comparativo que pressupõe uma sociologia. Se não chega a realizar trabalho de campo e por vezes reproduza generalizações típicas da chamada história conjectural, Mauss difere dos evolucionistas da época, como James Frazer, em cuja comparação "tudo se confunde e na qual as instituições perdem toda cor local e os documentos seu sabor" (MAUSS, 1974, p. 43). Por outro lado, ao contrário da comparação anti-evolucionista de RadcliffeBrown, o método de Mauss não exclui a história. Esta contribui e enriquece suas comparações. Mauss indica no Ensaio, assim como no texto sobre a noção de pessoa, escrito 15 anos mais tarde, que faz "história social", sem distinguir esta da "sociologia teórica", nem das "conclusões de moral [e] de prática política e econômica" (idem, p. 42-43).

Nesse momento do texto, Mauss pergunta-se qual a regra que estipula a retribuição, concluindo que cada sociedade tem a sua. Posteriormente, Lévi-Strauss (1949), proporá haver algo de universal por trás da diversidade no nível dos fatos, formalizando o "princípio de reciprocidade". Mauss entenderá a generalidade da retribuição "por meio de um número de fatos", sua análise permanecendo assim no nível das instituições particulares. Muitos dos críticos atuais da noção de troca de Lévi-Strauss "reduzem a troca a uma instituição" (VIVEIROS DE CASTRO, 1998), o que revelaria que "eles se acham na mesma situação intelectual de um século atrás" (LÉVISTRAUSS, 1998).

\footnotetext{
7 A noção de indivíduo de Mauss, enquanto unidade "fisiopsicológica", é apresentada em textos conhecidos de Sociologia e Antropologia.
} 
Eu dizia que Mauss generaliza a noção de contrato ao mesmo tempo em que a reformula. Ele não a usa no sentido de um contrato entre indivíduos, como faziam os filósofos dos séculos XVII e XVIII. É exatamente esse contrato maussiano que Lévi-Strauss substituirá pelo princípio de reciprocidade. Mauss também generaliza a noção de mercado - aliás, como outro grande estudioso das trocas arcaicas, da primeira metade deste século, Karl Polanyi (1980). Ambos irão supor que o mercado sempre existiu, mas a atenção de Mauss recai na diversidade das formas de troca, buscando uma comparação que procura "atingir uma dupla meta": entender "a natureza das transações humanas" de um modo geral e traçar a gênese de noções como "interesse individual" e do próprio sistema de mercado ocidental. Assim, se Mauss generaliza a noção de mercado, por outro lado ele tem consciência da importância de se pensar a especificidade do mercado ocidental. Nisso há uma recuperação de alguns dos objetivos de Karl Marx, que, apesar de evidente, tem sido pouco notada. Ainda como Polanyi, Mauss assume como universais as noções de mercado e contrato, mas não o homo xeconomicus ou as noções de "economia natural" e de estado de natureza (MAUSS, 1974, p. 44).

Como notei, a Antropologia maussiana diferencia-se da dos economistas liberais à medida que, no primeiro caso, "não são indivíduos mas coletividades que se obrigam mutuamente, trocam e contratam" (idem). Ou, por outra, as pessoas que trocam são "pessoas morais", não indivíduos. Nessas trocas, os grupos podem ser representados por seus chefes (idem, p. 45), mas apenas no capitalismo de mercado a troca é antes de mais nada entre indivíduos, pois esses são as pessoas morais no sistema. A gênese desse fato distintivo da modernidade é uma das preocupações de Mauss, posteriormente desenvolvida por L. Dumont.

Como vimos, para Mauss as trocas incluem bens mais ou menos alienáveis, assim como bens economicamente úteis ou não. Elas podem incluir "serviços militares, danças, festas, gentilezas, banquetes, mulheres"; em resumo, qualquer "circulação de riquezas" (incluindo-se aqui as mulheres) é apenas um momento "de um contrato mais geral e muito mais permanente" (MAUSS, 1974, p. 65). Ou seja, o objeto do Ensaio não é a economia primitiva, mas a circulação de valores como um momento do estabelecimento do contrato social.
Vimos ainda que Mauss chama essas prestações, esses diversos tipos de dádiva, de "totais". Uma forma, para ele "evoluída" e "agonística" de "prestação total", seria o potlatch dos índios da costa noroeste da América do Norte (kwakiutl, tsimshian, haida, tlingit, chinook etc.). Nesses casos, chefes, representando diferentes "linhagens" (ou, mais propriamente, "casas", como demonstrou Lévi-Strauss (1979)), competem entre si, oferecendo-se mutuamente quantidades cada vez maiores de bens, especialmente brasões de cobre esculpidos e peles de animais (posteriormente substituídas por cobertores industrializados, dado que estes teriam mais "valor" - SAHLINS, 1988). "Ganha" o chefe mais generoso. No potlatch, as posições políticas, na tribo e nas confederações de tribos, são constituídas pela rivalidade entre "casas" (Mauss ainda usa o termo de Boas, "linhagens"). A troca também pode aí assumir a forma de destruição de riquezas, os escudos brasonados de cobre jogados ao mar. No potlatch, a troca de certo modo substitui a guerra, mas guardando um sentido de rivalidade: vence quem dá ou destrói mais, a "luta dos nobres" é a luta dos grupos. Em certos potlatch, o chefe deve gastar tudo o que possui e nada guardar.

Mauss (1974, p. 47) reserva ao potlatch a denominação "prestação total de tipo agonístico". Isto é, implica um desenvolvimento da rivalidade, uma maior institucionalização da competição. Em outros lugares, as trocas assumiriam uma "forma mais elementar de prestação total", sem tanta competição, que seria uma "forma mais antiga da dádiva" e não seria o objeto de estudo do Ensaio (MAUSS, 1974, p. 98). Ao mesmo tempo em que sua comparação é cuidadosa, Mauss por pouco não propõe uma tipologia evolucionista, dado que a prestação total agonística deriva-se da prestação total simples. Digo "por pouco" porque o próprio Mauss não dá grande importância a esta classificação (das classificações nativas), importância que nós tampouco devemos dar. Fundamental nessa passagem da "Introdução" é a demonstração de como, nos potlatch, os fato da economia não se dissociam dos do direito. Mauss especifica a intuição de Durkheim de que a economia é, em última análise, regida pela religião, ou mais exatamente, por "mecanismos espirituais [...] regras e idéias" (MAUSS, 1974, p. 48) - a mais forte das quais sendo a própria obrigação moral de retribuição. 


\section{POLINÉSIA}

A Polinésia interessa especialmente a Mauss por causa da noção de mana, através da qual inicia seu estudo sobre a obrigação de retribuir. A noção de mana é também importante em partes da Melanésia, mas em um contexto de menor desenvolvimento da chefia como instância centralizadora da vida social. Essa noção permitiria comparações não só entre essas regiões próximas, mas também entre outras sem uma história de contatos: o potlatch da costa noroesta americana apresentaria noções semelhantes, implicando honra, prestígio e autoridade; não retribuir implica perda do mana.

Mauss inicia a análise da Polinésia por Samoa, salientando a presença de uma classificação de bens e pessoas em:

tonga (feminino) : oloa (masculino) : : inalienável : alienável : : autóctone : estrangeiro.

Essa relação entre gênero e inalienabilidade foi posteriormente estudada por A. Weiner (1976, 1992). Não só objetos mas também conhecimentos rituais são classificados como tonga; são as esteiras de casamento, herdadas pelas filhas, mas também os tesouros, talismãs, brasões, tradições, cultos e rituais. Eles pouco circulam. Proibições impedem-nos de serem repassados a qualquer um; ligam-se assim ao poder, daí serem bens de prestígio, freqüentemente marcas da chefia, carregados de mana.

Analisando as noções nativas de mana e de hau, Mauss conclui que "o que, no presente recebido e trocado, cria uma obrigação, é o fato de que a coisa recebida não é inerte". Nesse sistema, "o doador tem uma ascendência sobre o beneficiário" (Mauss, 1974, p. 54). A transmissão cria um vínculo jurídico, moral, político, econômico, religioso e espiritual, um "vínculo de almas. Presentear alguma coisa a alguém é presentear alguma coisa de si" (idem, p. 56). Tanto a quantidade e a qualidade do que é trocado tem importância no estabelecimento da superioridade política e moral como também a iniciativa do oferecimento de uma primeira dádiva que irá estabelecer a relação. Há algo de perigoso no ato de dar, há sempre o perigo de não sermos aceitos. A ascendência do doador se relaciona assim também à iniciativa da troca.

Em seguida, Mauss explica a destruição sacrificial a partir da lógica da reciprocidade, o sacrifício sendo uma doação que implica destruição e que deve ser retribuída pelos deuses (idem, p. 63). O sacrifício também é um contrato (idem, p. 65). Como no potlatch, os chefes aliados/ rivais polinésios se vêem mutuamente como deuses. Esse tema ainda merece mais estudos, assim como o das esmolas, também presentes tanto no contexto polinésio como no do noroeste norteamericano, e que podem ser definidas como "dádivas oferecidas às crianças e aos pobres [que] agradam os mortos" e aos deuses (idem, p. 6566). Mauss sugere haver uma relação entre esses temas, o sacrifício e a esmola: esta é um sacrifício feito às crianças e aos pobres ${ }^{8}$.

Mauss (1974, p. 67) nota ainda que a imensa maioria das sociedades polinésias apresentam sistemas monárquicos fundados em hierarquias de "clãs" (ou, como hoje sabemos, de "casas" - cf. LANNA, 1998). Essas monarquias seriam mais estáveis, a ponto de não necessitarem de instituições como o potlatch, cujo sentido seria o de "fixar por instantes" uma hierarquia". Assim, se os índios da costa noroeste evoluíram da prestação total simples à prestação total agonística, os da Polinésia teriam evoluído desta última à monarquia. Os maori seriam o povo polinésio onde as trocas mais se assemelhariam ao potlatch, porque lá os clãs estariam mais isolados, havendo entre eles maior rivalidade. Na Melanésia, o sistema de trocas se assemelharia mais ao potlatch do que na Polinésia, por não haver rígida e desenvolvida hierarquia. Esse raciocínio não é puramente evolucionista, pois concede que uma sociedade pode se desenvolver em diferentes sentidos, institucionalizando ora a dádiva, ora a centralização política. Até que ponto há evolucionismo na suposição da maior centralização representar um sentido geral é uma questão ainda sem resposta na Antropologia de hoje, como revela o colóquio que se reuniu para discutir esse tema e

\footnotetext{
8 Sobre a associação entre as crianças e os mortos, presente em um grande número de sociedades, cf. Lévi-Strauss (1952).

9 Note-se que tanto as sociedades polinésias como as da costa noroeste da América vêm sendo interpretadas como "sociétés à maisons" (LÉVI-STRAUSS, 1979). Mauss aponta haver uma maior instabilidade política nessa região do globo, uma menor centralização da instituição da chefia e, logo, a não existência de monarquias, como as que encontramos na Polinésia.
} 
que redundou na coletânea de artigos organizada por Godelier, Trautman \& Tjon Sie Fat (1998).

\section{A EXTENSÃO DESSE SISTEMA}

Nesta parte do texto, Mauss ambiciona mostrar a generalidade da lógica da dádiva, por ele esboçada anteriormente. Comenta que comparar civilizações não implica desvendar as "conexões" entre elas. Antropólogos hoje concordam com esta posição. Por exemplo, a crítica de Lévi-Strauss $(1958,1992)$ a Boas revela de modo definitivo que a dificuldade no sentido de estabelecermos conexões históricas não nos impede de buscarmos conexões lógicas entre elas (cf. também os quatro volumes das Mythologiques). De todo modo, é fundamental a demonstração de Mauss de poder a troca gerar valores sociais e que sua associação à rivalidade é bastante generalizada nas sociedades humanas - não só porque dar freqüentemente significa obter prestígio, mas também por que a troca incorpora nela mesma algo da guerra. Para usar a terminologia da teoria da hierarquia de L. Dumont (1992), é como se o dar englobasse o receber (o oposto talvez defina o capitalismo e a troca mercantil, tal como definida por Marx, visando ao lucro em dinheiro). Em todo caso, trocando, domestico meu parceiro, e se for bem sucedido, se der mais do que recebo, posso fazer dele, segundo uma metáfora melanésia, "um cachorro que vem lamber a mão do dono" (idem, p. 81).

As dádivas perpassam e organizam diferentes esferas sociais. Mauss dá vários exemplos (ilhas Andaman, China, Polinésia) de como o casamento pode ser entendido como a dádiva de uma mulher. $\mathrm{Na}$ verdade, o casamento envolve uma série de dádivas entre grupos aliados, a dádiva da mulher sendo concebida como a "principal", aquela que fundamenta a instituição (como o voto pode ser concebido em alguns lugares como a dádiva principal, que fundamenta as eleições - cf. Lanna, 1995). No casamento, a dádiva da mulher freqüentemente é acompanhada, como na nossa sociedade, de outras dádivas, feitas a um dos cônjuges (por exemplo, o dote, tão importante na Europa ocidental do século IV até a revolução industrial cf. Goody, 1983) ou à familía de um deles (como no caso da riqueza da noiva, tão importante em toda a África sub-sahariana - cf. Goody, 1973). O casamento pode ainda ser uma ocasião propícia para um potlatch (Mauss, 1974, p. 107), sendo neste caso a prestação englobada (Sahlins, 1988), não a englobante.
Mauss repete observações de que as trocas de dádivas assumem múltiplas formas e conteúdos. Elas podem levar à superação de um estado de guerra. Ou ainda, como entre os andamaneses, por exemplo, entre outras sociedades, serem associadas não à aproximação mas à interdições, respeito, ritos de separação e evitação; isto é, elas criam uma relação e ao mesmo tempo sacramentam uma distância entre os parceiros. As dádivas podem ainda se relacionar ao contrário da evitação, às relações jocosas entre afins (Mauss, 1974, p. 70).

Após passar em revista a descrição dos andamaneses de Radcliffe-Brown, Mauss aborda descrição dos trobriandeses feita por Malinowski. Coerentemente com sua suposição de uma universalidade do mercado, Mauss (idem, p. 8889) define como moeda os vaygu'a trobriandeses, os braceletes e colares que são os valores máximos trocados entre diferentes ilhas no conhecido circuito kula. Mauss ainda não percebe a importância das esferas distintas de troca implícita na classificação trobriandesa, fenômeno caracteristicamente ligado à dádiva, como mostraria mais tarde a Antropologia econômica (cf. Lanna, 1998, ou ainda os capítulos iniciais de Giannotti, 1983). Isto é, no sentido marxista inclusive, a moeda define-se por sua capacidade em generalizar-se, permitindo a conversão entre diversas esferas de troca. Assim, não se pode associar diretamente, numa sociedade africana que pratique a riqueza da noiva, por exemplo, a dádiva da mulher às outras prestações materiais que acompanham o casamento, o que levou antropólogos como James Frazer a erroneamente falarem em "compra de mulheres".

O próprio Mauss $(1974$, p. 75$)$ nota que Malinowski criticou, a meu ver corretamente, a sua concepção de moeda, pois esta implicaria apenas a noção de meio de troca e não de padrão geral de valor. Isto é, Mauss não parece ciente da especificidade da moeda capitalista, como um "valor que se generaliza" de modo não hierárquico. Nas sociedades não-capitalistas, os valores só se generalizam de modo hierárquico (sempre no sentido de Dumont). Isto é, o valor de certos objetos pode não ser no sentido de sua generalização quantitativa, como padrão ou medida da troca. Por exemplo, seu valor pode estar em uma capacidade regenerativa milagrosa (ou "lifegiver") ou em uma capacidade emblemática para representar todo um clã ou linhagem (caso das 
esteiras polinésias mencionadas por Mauss). Nesse caso, tratam-se de valores "subjetivos e pessoais", freqüentemente inalienáveis. O que distingue a moeda capitalista das "moedas" hierárquicas é que estas são menos alienáveis. Claro que elas também não são totalmente inalienáveis, pois por definição são passíveis de serem trocadas, apesar de essa troca ser sempre cercada de proibições e condições (ocorrer só quando há um casamento real, por exemplo).

Já no capitalismo, a moeda destrói as esferas de troca, acabando com a possibilidade de uma dessas esferas vir a ser hierarquicamente superior. A divisão fundamental passa a ser entre o que é ou não é mercadoria, isto é, passível de compra e venda, ser trocado por dinheiro; no mercado, a moeda passa a ser uma medida geral. Como indicava Malinowski (e mais recentemente, Barraud et alii, 1984) a moeda hierárquica também é uma medida geral, mas não no sentido de poder ser diretamente trocada por qualquer objeto. No capitalismo, a própria alienabilidade passa a ser um valor; todos desejam a moeda por esta ser aquilo que pode, potencialmente, tudo alienar. Assim, se a lógica da mercadoria define uma esfera extremamente ampla de troca -, o mercado -, a da dádiva define sempre várias esferas restritas, fechadas em si mesmas, mas em relação hierárquica entre elas. Mauss poderia ser criticado por não distinguir a generalização de valores hierárquicos (no sentido dumontiano do termo) da generalização capitalista do valor e do valor-moeda (no sentido marxista do termo).

De uma perspectiva marxista, Mauss poderia ainda ser criticado por freqüentemente não distinguir o que Marx denominava "gênese lógica" da "gênese histórica da moeda". Nas reflexões sobre a moeda do Ensaio, fica implícito, a todo momento, que Mauss não deixar de buscar a "origem" da nossa moeda. No caso do cobre kwakiutl, por exemplo, Mauss impressiona-se com o significado desse bem tão valorizado e ao mesmo tempo tão pouco alienável. Por outro lado, para ele importa também pensar a sua própria forma (cobre), pois ela poderia representar uma continuidade com a moeda capitalista.

Apesar dessa criticável preocupação com origens históricas, que, ao modo dos evolucionistas do século XIX, fundamentaria algumas das comparações de Mauss, o autor está ciente de que os cobres dos índios da costa noroeste da América do Norte teriam um significado construído localmente. Seriam assim "moeda", a meu ver, não por sua forma (cobre), mas por sua capacidade para representar um todo, ao serem associados ao chefe. Quanto a esse significado do cobre no contexto kwakiutl, lembro que para Mauss a chefia engloba o cobre. Por outro lado, o chefe não apenas possui um cobre, mas ele mesmo é um cobre quebrado, os cobres são o seu espírito (Mauss, 1974, p. 127-128). O cobre seria uma moeda personalizada, que inclusive fala e isso, para Mauss, o diferiria fundamentalmente da nossa moeda. Mas não tanto: "serve-se do cobre por percussão, como no direito romano: cunha-se nele o gens ao qual são dados [...] coisas tocadas pelo cobre são-lhe anexadas, mortas por ele; esse, aliás, é um ritual de paz". Assim, "as coisas têm uma personalidade e as personalidades são, de certa maneira, coisas permanentes do clã" (Mauss, 1974, p. 128).

Essa concepção de moeda de Mauss leva-o então a tratar a dádiva como comércio. Mas ele deixa claro que, se a dádiva também é comércio, ela não é exclusiva nem principalmente comércio; seria apenas um dos seus sentidos, seu "aspecto econômico". O kula, por exemplo, pode ser entendido como um comércio intertribal, por implicar uma troca circular que ocorre entre várias ilhas melanésias. Mas, como Malinowski mostra, ele é distinguido pelos próprios trobriandeses das trocas puramente econômicas "de mercadorias úteis", denominadas gimwali, e que ocorrem paralelamente a ele (idem, p. 74). Mauss nota que os trobriandeses sempre foram comerciantes. Em resumo, para Mauss, como para Malinowski, as trocas podem ter um caráter mais ou menos comercial.

Após refletir sobre a noção de moeda, em geral, a partir do kula e do potlatch, Mauss salienta uma semelhança entre essas duas formas de troca: ambas são "de ordem nobre" (Mauss, 1974, p. 73). Note-se que a comparação não é tanto entre sociedades, isto é, não é aquela que propunham na mesma época Boas, Malinowski e RadcliffeBrown, cada qual ao seu modo. Não há um esforço para uma contextualização totalizadora da mesma ordem da que encontramos naqueles grandes etnógrafos. Trata-se, no caso de Mauss, de comparar formas de troca, ou manifestações específicas de instituições que se revelam fundamentais em diferentes sociedades. 
Mauss aponta ainda para outra questão importante, o fato de que cada sociedade faz sua hierarquia entre as esferas sociais. Posteriormente, Godelier (1981), entre outros autores, retoma esta tarefa fundamental de entender a hierarquia entre as esferas sociais de cada sociedade. Para Godelier, a esfera fundamental, fosse ela qual fosse, "funcionaria" sempre como "relação de produção" (economia no capitalismo, religião na Índia, política no final do feudalismo europeu, parentesco na Austrália etc.).

Em um debate que é até hoje retomado entre Marx e Mauss, este último faz outra contribuição fundamental ao salientar, com base nos dados de Malinowski, que a produção dos objetos kula, os vaygu'a, não parece ser tão relevante quanto sua troca (Mauss, 1974, p. 86). Ou, por outra, as relações de produção são nas Ilhas Trobriand determinadas pela dádiva, assim como a produção dos vaygu'a é subsumida na sua condição de dádiva fundamental.

Ainda a partir da etnografia de Malinowski, Mauss retoma as diversas formas de dádivas trobriandesas (inicial, de fechamento, convite, de retorno etc.) interpretando-as como "formas primitivas de classificação" 10 . Corretamente, não dá atenção à (re)classificação malinowskiana desta classificação trobriandesa. Sugere futuras pesquisas sobre o lugar do indivíduo não generoso no kula, infiel aos seus parceiros, e conclui que "o kula não passa, ele próprio, de um momento, o mais solene, de um vasto sistema de prestações e contra prestações que parece englobar a totalidade da vida econômica e civil dos trobriandeses" pois "ele concretiza e reúne muitas outras instituições" (idem, p. 83). O kula é assim um fato fundamental da vida trobriandesa, englobando não só o que Mauss chama de "vida civil e econômica" (incluindo aqui a política e a diplomacia intertribal) como também os mitos, a religião, a magia, as

10 Mauss, entretanto, ora reconhece o "refinamento" (1974, p. 89) intelectual das classificações trobriandesas, ora as toma como "pueril" (idem, p. 88). Mas sua análise não deixa de relacionar as classificações nativas das trocas à morfologia de cada grupo. A troca pode, assim, envolver em cada caso mais ou menos os chefes, clãs, fratrias e confrarias (idem, p. 104), ou um potlatch que tem como causa um funeral pode ser, em um dado grupo, distinguido de outros tipos de potlatch (idem, p. 114), e assim por diante. práticas funerárias e a moral (Mauss, 1974, p. 86).

Fiz alhures (Lanna, 1992) uma discussão sobre este aspecto englobante do kula, apontando para um fato não salientado por Mauss: a produção e a troca de bens não-kula, aqueles excluídos da esfera de troca dos vaygu'a, são função das relações de parentesco. Ou mais precisamente, nas Ilhas Trobriand, a troca de mulheres funda uma relação de vassalagem, denominada urigubu, na qual o doador de mulheres recebe prestações de inhames - às quais tanto Mauss como Malinowski se referem como "tributos". Os chefes trobriandeses arrebanham vassalos "distribuindo" suas filhas como esposas. Mauss (1974, p. 87) lembra como é importante a redistribuição, feita pelo chefe, dos objetos trazidos por uma expedição kula "aos grupos que prestaram serviços ao chefe ou ao seu clã". Se o urigubu é um mecanismo endógeno de criação do poder do chefe, no kula tudo se passa como se este poder se fizesse de fora para dentro, ao trazer valores kula do exterior. É nesse contexto que deve ser entendida a afirmação de Mauss de que a troca kula organiza todas as relações do grupo, inclusive as internas.

Vimos que o kula envolve diversos grupos melanésios e que Mauss interpreta como "moeda" certos objetos melanésios que são a devida recompensa ao oferecimento de "cantos, mulheres, serviços” (MAUSS, 1974, p. 90). É interessante que também no potlatch haja a troca de "cantos, mulheres e serviços" pelos cobres e pelas peles (SAPIR, 1994). Como os objetos melanésios, cobres e peles da costa noroeste americana realmente se assemelham à moeda que representam valores sociais centrais. Sugerem ainda a idéia de casamento por meio da compra, mas Mauss já indicava ser imprópria essa expressão, pois esse casamento "na verdade compreende prestações em todos os sentidos, inclusive os da família da mulher", isto é, há uma superposição de diversos circuitos de troca.

Mauss conclui sua observações sobre os melanésios negando que eles sejam menos evoluídos, mas simplesmente "não têm nem a idéia da venda [...] e contudo fazem operações jurídicas e econômicas que tem idêntica função" (idem, p. 91). Lembra ainda que eles são "uma parte da humanidade, relativamente rica, laboriosa e criadora de excedentes importantes" (idem, p. 92). Diz o mesmo dos índios da costa noroeste da América, que desenvolveram uma rica civilização 
material e espiritual, como demonstram, por exemplo, suas esculturas, mas, curiosamente, não conheciam nem a agricultura nem a cerâmica. Após o contato com os brancos, esses índios não só mantiveram como desenvolveram o potlatch. Vimos que, em relação aos sistemas de dádivas do Pacífico sul, os índios da costa noroeste apresentam maior rivalidade e um certo elemento de violência, a "guerra de propriedade"; outra diferença relevante, salientada por Mauss, seria a de terem elaborado mais "a noção de crédito a prazo" (idem, p. 96).

$\mathrm{O}$ fato de trocas do tipo potlatch obedecerem a um crescendo foi entendido por Boas como uma manifestação daquilo que concebemos como empréstimos a juros: deve-se sempre dar mais do que se recebeu em um potlatch anterior. Mauss sugere substituir os termos dívidas, pagamento, reembolso e empréstimo, mas mantém o de juros - chega a falar em "taxas" (idem, p. 112). Argumentei, ao contrário, a favor de mantermos como universal a noção de dívida, mas não a de juros (LANNA, 1995). Em todo caso, não podemos jamais tomar a noção de crédito como sinal de uma evolução, como supõem alguns historiadores econômicos e o próprio Mauss, na parte III do Ensaio, como veremos a seguir.

O potlatch sugere a Mauss outros insights, como o de que o jogo e a aposta, mesmo entre nós, são formas de potlatch: neles "empenha-se a honra e o crédito [e], não obstante faz-se circular a riqueza". Mauss supõe ainda haver uma associação universal (evidentemente que institucionalizada diferentemente em cada caso) entre troca e sacrifício (MAUSS, 1974, p. 99); o dar seria associado à vida e o receber à morte. Fica a impressão de que essa "tendência" se enfraqueceria no capitalismo. No potlatch, muito claramente, é o receber e não o destruir que é associado à morte. Destruir seria uma forma de dar, uma forma muito específica exatamente porque evita a retribuição (idem, p. 100). Do ponto de vista do doador, "dar já é destruir", um sacrifício, logo um modo de dar vida, de regeneração social. Ao se destruir, tira-se a vida do objeto, mas recria-se a vida do doador. Freqüentemente, no noroeste da América a destruição pode ser pelo fogo (queimam-se casas do próprio grupo) ou atiram-se os cobres ao mar. Alternativamente, quebram-se os cobres em pedaços (o que, por sinal, não implica necessariamente que eles deixem de circular).

Ao analisar o potlatch Mauss nota ainda a associação entre troca e circulação de nomes ${ }^{11}$. Dá-se um potlatch para ganhar, manter ou recuperar um nome, geralmente nome de linhagem. Ganha-se assim reputação. Obviamente os insights de Mauss não se limitam ao potlatch. $\mathrm{O}$ estudo das trocas permitem-no relacionar o mana polinésio e melanésio ao "homem largo" da costa noroeste da América e à autoridade romana. Nos três casos trata-se da associação entre honra e magia, prestígio e riqueza. Mauss (1974, p. 102) nota que o mesmo ocorre "nas tribos realmente primitivas, como as australianas".

Ao mesmo tempo, perder um potlatch pode gerar escravidão (idem, p. 105), ou ainda, dá-se um potlatch para se "resgatar cativos" (idem, p. 107). Em resumo, o potlatch indica como a dádiva pode se ligar simultaneamente ao sacrifício, ao nome e à escravidão. Isso implica, entre outras coisas, sua relevância para o entendimento das mais variadas sociedades, dos indígenas amazônicos à Roma antiga. A autoridade é assim um conceito romano que não apenas ou não fortuitamente lembra o de mana: há em torno de ambos semelhantes "arcabouços institucionais". Assim, o nexum (idem, p. 112) é um conceito romano que lembra a "escravização por dívida" da costa noroeste; em ambas "empenha-se o nome".

Mauss está consciente que apenas inicia comparações possíveis a partir da noção de dádiva. As comparações que faz são bastante intuitivas mas também bastante ousadas. Sugere que o potlatch nos permite repensar o feudalismo europeu. Há entre os tsimchian, por exemplo, dois tipos de potlatchs, o dos chefes e os de vassalos (idem, p. 107, nota 170). Mas, mais comumente, o potlatch se liga à confederação de tribos, estabelecendo uma hierarquia entre chefes. Eles têm entre si relações vassalo/suserano; perder um potlatch é tornar-se ora escravo, ora vassalo. Em alguns casos, estabelece-se que para vencer um

\footnotetext{
11 A análise de Mauss é a meu ver muito mais sugestiva que certos desenvolvimentos da Antropologia da Melanésia, que associam a circulação de nomes em trocas do tipo kula à noção de fama e não à onomástica ou à distribuição de títulos (cf. MUNN, 1986; WEINER, 1976, entre outros).
} 
potlatch, tornar-se suserano, deve-se antes ter perdido, ter sido vassalo, recebido bens que seriam futuramente dados (idem, p. 105). Por outro lado, o que um chefe recebe no potlatch de outro chefe, é necessariamente por ele redistribuído internamente (idem, p. 107). O chefe que perde um potlatch não perde totalmente sua autoridade, pois é um intermediário; ele está então em condições de passar adiante algo da alma, da identidade, do ser do vencedor. O perdedor tem assim duas possibilidades: a primeira seria, a partir dos valores que recebe e de outros que pode vir a acumular, tentar ganhar outro potlatch no futuro; a segunda seria passar a ser um representante do vitorioso, ainda que tendo seu prestígio diminuído em relação a este.

Neste momento do texto (o sub-item do "Capítulo I"I, intitulado A força das coisas), Mauss adota o conceito de mana para explicar fatos da costa noroeste americana. É famosa a crítica de Lévi-Strauss (1974) a esta passagem, que tem sido entendida como uma censura ao fato de Mauss tomar a teoria nativa como teoria antropológica. A meu ver, o problema dessa passagem é não só o fato de Mauss generalizar uma noção particular, a de mana, como aponta Lévi-Strauss, mas também aproximar categorias nativas muito distantes, romanas, samoanas e kwakiutl. De modo semelhante, é evidentemente errônea a afirmação de Mauss de que o potlatch existe na Melanésia. Hoje sabemos que o que é geral é o princípio de reciprocidade, formalizado por Lévi-Strauss (1949), a partir do próprio Ensaio sobre a dádiva. Por outro lado, Mauss (1974, p. 121) encontra na noção de logwa, da costa noroeste, um equivalente ao mana. Ambas teriam uma "virtude produtora" (ibidem). É como se houvesse uma funcionalidade (ou efi-cácia?) de uma ideologia, ou melhor, de um "prin-cípio mágico e religioso da posição e da abundân-cia" (idem, p. 121-122), isto é, não exatamente de um princípio político-econômico.

Como já disse, Mauss nota que, em toda parte, distinguem-se bens mais ou menos inalienáveis, e que os segundos são sempre os mais valiosos mulheres, privilégios que se passam a um genro ou nomes a um filho. Da mesma forma, distinguem-se, em toda parte, como entre nós, os "alimentos ricos" das "simples provisões". Para Mauss, seria mais correto falarmos não em troca mas sim em "empréstimos" entre bens inalienáveis. Os títulos, como o de xamã ou de titular de danças em uma confraria (idem, p. 118) podem ser tidos como bens inalienáveis. São "coisas da família" (idem, p. 119). No caso da costa noroeste americana, casas, portas, talheres, mantas, caixas, pratos, canoas, cachorro seriam, neste sentido, semelhantes às nossas "coisas da família". Elas são, como todas as dádivas, individualizadas; como cada um dos objetos kula, cada uma destas "coisas da família" é identificada por um nome e tem sua história própria.

Exatamente por sua inalienabilidade Mauss (1974, p. 121-122) também associa os cobertores da costa noroeste às esteiras polinésias, por serem "bens essenciais de circulação bastante estrita, cuidadosamente repartidos entre os clãs e as famílias dos chefes". Eles seriam ainda semelhantes a certos objetos kula, também bens de circulação restrita a uma esfera de troca e às ocasiões solenes de kula. Mauss nota que um cobre que já foi destruído e depois reconstruído, isto é, já passou por vários potlatch, tem mais valor (idem, p. 125). Mas Mauss nota ainda que os kwakiutl distinguem duas espécies de cobres, distinção feita com base na maior ou menor alienabilidade (ibidem). Isto é, há cobres que não saem da família e que não deixam de ter grande valor, equivalente ao da família. $\mathrm{O}$ valor máximo seria então o de um cobre-de-família-nobilérrima-que-circulou que realiza a síntese entre inalienabilidade e alguma alienabilidade. Essa interpretação se reforça pelo fato de que os cobres secundários não podem ser quebrados e refundidos; são "satélites dos primeiros", exatamente porque são definidos, de antemão, como mais alienáveis.

\section{DIREITOS E ECONOMIAS ANTIGAS}

O título do "Capítulo III" do Ensaio é "Sobrevivência desses princípios nos direitos antigos e nas economias antigas". Como se sabe, a noção de sobrevivência foi cara aos evolucionistas. Também a noção de antigüidade sugere um estágio entre a modernidade e o primitivismo. Sugeri acima que as comparações de Mauss estão de certa forma entre Boas e Frazer, dirigindo-se para a perspectiva mais etnográfica do primeiro sem abrir mão da pretensão para encontrar traços universais do pensamento humano que caracterizava o segundo. O título do "Capítulo III" indica que Mauss não se livrou totalmente de influências evolucionistas. No segundo parágrafo deste terceiro capítulo, Mauss fala em comparação (Frazer) $e$ explicação histórica (Boas), de certo modo confundindo ambos os métodos. A meu ver, como 
seu título indica, este é o capítulo mais evolucionista do Ensaio, justamente porque também é aquele com mais pretensões históricas. A história de Mauss difere assim da de Boas por não perder uma obsessão com a noção de origens. Esse evolucionismo não é, entretanto, a característica central do texto, nem invalida inúmeras de suas contribuições.

De um ponto de vista metodológico, o evolucionismo do capítulo expressa-se ainda pelo fato de Mauss apoiar-se não na lingüística porém sim na filologia. Mas o próprio Mauss (1974, p. 147) parece consciente dos limites deste procedimento, quando indica que não irá aprofundar sua "tentativa de reconstrução por etimologia". Também na parte dedicada aos fatos indianos, Mauss mostra-se consciente dos limites de sua preocupação com origens (p. 143-144), afirmando a seguir que "nossa demonstração atual não nos obriga a dosar estas múltiplas origens e a reconstituir hipoteticamente o sistema completo" (idem, p. 147). Conclui, como faríamos hoje, que "a simples descrição será bastante demonstrativa" (idem, p. 148). Quanto à identificação entre comparação antropológica e trabalho histórico, está claro que ela se limita a algumas passagens do texto, pois, como vimos, há no Ensaio inúmeras passagens onde a comparação prescinde a abordagem histórica, fundamentando-se no próprio fato da troca de dádivas, pressupondo assim mais a análise sociológica que a histórica.

É ainda no "Capítulo III" que surge a idéia de que "entre nós", isto é, na sociedade capitalista, a dádiva se enfraquece, ao opor-se à obrigação e à prestação não-gratuita (idem, p. 132). Mauss (1974, p. 143-144) supõe neste capítulo que, do ponto de vista moderno, a moral da dádiva seria "envelhecida e acidental", e "demasiado dispendiosa e suntuária, assoberbada por considerações pessoais, incompatível com o desenvolvimento do mercado e da produção".

Ao mesmo tempo, ao abordar a instituição romana do nexum, Mauss nota que ela fundaria as noções de crédito e penhor, estando a meio caminho entre a economia capitalista e a da dádiva. Mauss não chega a reproduzir o erro dos historiadores econômicos que critica (Mauss, 1974, p. 98) por suporem ser o crédito uma conquista da evolução da humanidade, mas sua abordagem não deixa de ser evolucionista. Como já disse a respeito das interpretações de Mauss sobre a moeda, ao contrário de Marx, Mauss parece confundir evolução lógica com a histórico-factual. De todo modo, Mauss (1974, p. 134) mostra que, no nexum romano, o credor se vincula ao devedor como o recipiente de uma dádiva ao seu doador: em uma relação de empréstimo, "o indivíduo que recebeu a coisa é ele mesmo, ainda mais que comprado, aceito pelo empréstimo"; ou ainda, "o mero fato de ter aceito algo de alguém torna o indivíduo obrigado" (ibidem).

Em Roma não teríamos ainda, num primeiro momento, a compra e a venda, mas sim a entrega de um bastão (de cobre) junto com a coisa emprestada. Esse bastão foi posteriormente substituído pela moeda, representando um título que empenhava o gado das gentes, e que tinha cunhada sua face. A moeda teria sido então antes um penhor, depois um valor ${ }^{12}$. Essa sugestão parece factível para o caso romano. De qualquer modo, ainda que as generalizações históricas de Mauss possam ser criticadas, fica a sugestão genial, ainda que apoiada na etimologia e na intuição sociológica: vendere foi "originariamente venum-dare" (idem, p. 142).

Mencionamos que a noção de contrato tem, para Mauss, caráter universal. Coerentemente, para ele o nexum seria, como o potlatch e o kula, um contrato, implicando algo mais que um vínculo mágico, religioso e jurídico - o que aliás já era notado pelos romanistas da época. Mauss (1974, p. 136) sugere associarmos esses aspectos do vínculo (ou nexum), isto é, sua "semelhança" com o potlatch ou o kula, ao fato de a família romana incluir os escravos e as coisas. Estas coisas se dividiam em res mancipi e res nec mancipi, isto é, alienáveis ou não. Mauss afirma que a pecúnia, o gado, que se tornou moeda, pecúlio, era o bem alienável por excelência, isto é, o que menos representava a família e a casa. Segundo a classificação romana, ele estaria, mais do que qualquer outro bem da família, próximo das "coisas que passam", comerciáveis.

Mauss nota a associação entre essas "coisas que passam" e a idéia de tradição. A raiz dessa palavra é a mesma da palavra que significa "comércio" em inglês (trade). A idéia é que as

12 É interessante notar que a noção de valor não seria para Mauss universal. Dumont, ao contrário de seu mestre Mauss, generaliza a noção de valor, mas não a de moeda. 
coisas criam vínculos espirituais: tradição. Neste sentido, a tradição é o que fica daquilo que passa. Mauss nota que "os romanos não tinham outra palavra além de dare, dar, para designar todos esses fatos que consistem na traditio" (idem, p. 142). Não há assim novidade na sugestão, feita por certos cientistas sociais anglo-saxões, que certamente leram mal Mauss, de que as tradições são dinâmicas ou "inventadas".

Por mais que se possa criticar Mauss por fazer comparações intuitivas, sem distinguir perfeitamente as conexões lógicas das históricas, sua análise revela claramente a importância do estudo da dádiva para entendermos os direitos romano e germânico. Por exemplo, Mauss nota que a noção romana de réu, antes de assumir o sentido de "culpado", indicava o homem possuído pela coisa. A "inferioriedade espiritual" que caracterizaria aquele que recebe algo seria uma "quase culpa" (idem, p. 140).

Em seguida Mauss aborda o direito hindu clássico, do qual há numerosas fontes escritas, verdadeiras "epopéias da dádiva", até hoje "extremamente populares na Índia" (idem, p. 144-145). Como o direito germânico, o hindu teria conservado um sistema moral fundado na dádiva que representaria uma etapa "anterior" (lógica e historicamente) aos direitos grego e romano. Mauss (1974, p. 145) espera poder revelar, através "da teoria das dádivas" elaborada pelos próprios hindus, uma continuidade entre estes direitos e a moralidade cristã.

Havia na Índia a prescrição de se dar aos brâmanes, superiores hierárquicos. Nesse caso, Mauss não chega a falar em tributos. Essas prestações religiosas eram claramente sacrificiais e retribuídas pelos brâmanes com serviços religiosos. Os brâmanes "encarregariam os deuses de retribuir os presentes feitos a eles". Mauss fala em uma série de presentes aos deuses, sem descrevê-la precisamente, praticada tanto por brâmanes como pelo "comum dos mortais". Aparentemente, tratase de "repastos funerários". Mauss afirma que "faltam dados" e que não haveria necessidade de esses fatos serem "especificados com precisão em um trabalho de comparação" (idem, p. 148). Tratar-se-ia de um "direito" que esteve em vigor na prática do séc. 8 a. C. até o $3 \mathrm{~d}$. C., mas que sobrevive até hoje na "lei brâmane" (ibidem). O "Mahabarata é a história de um gigantesco potlatch [...] torneio e escolha de noivas" (idem, p. 147). A
Índia antiga teria sido um "país de potlatch" (idem, p. 145), de "prestações totais de clãs e aldeias", apesar de já conhecer "o mercado, o mercador, o preço, a moeda, a venda". Mauss fala em rituais da venda, que se associariam aos "princípios de hospitalidade" (idem, p. 146).

Mauss comenta que uma dádiva produz sempre sua recompensa. No caso hindu, essa recompensa pode ocorrer nesta ou em outra vida. A dádiva "não é perdida, reproduz-se" (idem, p. 148), volta de alguma forma ao doador inicial. Assim, um avaro "renasce em uma família pobre" (idem, p. 148). Trata-se assim de uma "teologia jurídico-econômica" (idem, p. 149) presente nas leis e na prática cristã. Entre os brâmanes, como entre os cristãos, prega-se que o "verdadeiro lucro" implica "renúncia de si" (idem, p. 149).

Mauss lembra ainda ser bastante geral a crença de que aquele que consome sem dar (isto é, sem ser consumido) é tido como alguém que consome veneno. Há, assim, também na Índia, a equação já mencionada acima, entre dar e viver. Associado ao viver, o dar é pensado no caso indiano como qualidade natural: "tudo que se é dado são seres vivos, com os quais se dialoga e que tomam parte no contrato" (idem, p. 149). Ou ainda: "é da natureza da comida ser partilhada" (idem, p. 150). Se o entesouramento é associado à morte, o dar é associado à vida e à noção, fundamental na Índia (DUMONT, 1992), de pureza.

Mauss nota que "tal é a interpretação ao mesmo tempo materialista e idealista que o bramanismo deu para a caridade e a hospitalidade" (idem, p. 150). Do ponto de vista da organização social e política, o sentido da riqueza é ser dada aos brâmanes. Há dois modos de destruição: um, antisocial, é associado à avareza; o outro, do sacrifício brâmane, é associado ao seu oposto, a generosidade divina. Ao mesmo tempo em que vivem das dádivas, os brâmanes fingem recusá-las; são recebedores na prática, mas definidos ideologicamente (num sentido forte) como doadores, encarnando os valores máximos daquela sociedade. Recebendo algo de toda a sociedade, inclusive dos reis (os kshatriyas, em relação aos quais são superiores), os sacerdotes a encarnam: cada um dá um pouco de si e o todo se representa no brâmane.

Já a civilização germânica, segundo Mauss, não teria teorizado tanto sobre a dádiva como a hindu, mas não teria deixado de praticá-la. Diferiria ainda da hindu por ser "essencialmente 
feudal e camponesa" e "desprovida de mercados" (idem, p. 156). Analisando os germanos, Mauss nega a tese da existência de uma "economia fechada", tese esta que viria a se tornar incrivelmente comum nas ciências sociais do segundo pósguerra, tanto nos desenvolvimentos dos trabalhos do próprio Mauss feitos pela chamada "Antropologia econômica" como, por exemplo, nos chamados "estudos de comunidade", de inspiração norte-americana. Mauss (1974, p. 156) mostra como toda sociedade tem suas formas de exogamia, suas trocas de mulheres, bens, ritos etc. Apresentando um argumento posteriormente desenvolvido por Lévi-Strauss (1952, entre outros), Mauss indica que, ainda que possa haver certo isolamento, ele é sempre relativo, restrito, por exemplo, no caso da civilização germânica, a uma certa época do ano. Mauss (1874, p. 157) nota que as famílias, tribos, chefes e reis germânicos se comunicavam através de festas, alianças, penhores, hospedagens e presentes "tão grandes quanto possível". Batismos, comunhões, noivados e casamentos incluíam banquetes nos quais os convidados poderiam ser "todo um povoado". Um casamento real germânico lembraria o caso brâmane: o casal real recebe não em nome da avareza mas do seu oposto, sua fertilidade sendo aquela de todo o reino; este, por sua vez, é representado pela soma das dádivas recebidas pelos nobres noivos. Como no caso dos tributos, os bens possibilitam ao rei representar o todo.

Mas não só em casamentos reais "a generosidade das dádivas é um penhor da fertilidade do jovem casal". Por isso mesmo, refletir sobre a instituição do casamento nos ajuda a entender o significado do penhor. Evitamos assim pensar os fatos econômicos como se fossem fatos puramente econômicos. Mauss (1974, p. 157) fala que casamento e penhor são instituições de mesma "origem", havendo "a necessidade do penhor em todas as espécies de contratos germânicos". Este penhor teria dado origem à própria noção de salário (wadium, wage): "o penhor aceito permite aos contratantes do direito germânico agir um sobre o outro, pois um possui algo do outro" (idem, p. 158). O penhor era em geral um objeto pessoal, de pequeno valor, como uma luva, uma moeda ou uma faca. Aquele que o entregava empenhava a sua honra, ficando em uma posição inferior até a quitação do contrato. Há assim um perigo em dar e em receber, seja uma dádiva, seja um penhor. Lembrando uma representação que vimos estar presente na Índia, nas línguas germânicas a palavra gift tem o duplo sentido de dádiva e de veneno. $\mathrm{O}$ tema da "dádiva funesta" é comum no folclore germânico.

Também a civilização chinesa reconhece o vínculo entre o doador e o bem dado, "mesmo hoje em dia" (idem, p. 161). Também lá "aceitar um presente é perigoso". Mauss se aproxima das reflexões de Karl Polanyi (1980) a respeito da mercantilização da terra, quando observa que "na história humana a venda definitiva da terra é muito recente" sendo por isto "normal que a terra escape ao direito e à economia do capital" (1974, p. 161, nota 125). Isso explicaria em parte, a meu ver, a força do movimento comunista chinês e da nossa própria idéia de reforma agrária: nada menos capitalista do que uma dádiva do Estado. Distancio-me assim de J. T. Godbout (1998, p. 44), quando este afirma que "entende-se por dádiva tudo o que circula na sociedade que não está ligado nem ao mercado nem ao Estado (redistribuição) nem à violência física". Quanto à relação entre dádiva e violência física, remeto o leitor, entre tantos outros, ao texto de Carneiro da Cunha \& Viveiros de Castro (1985). Ao contrário de Godbout (1998, p. 47), penso que, para Mauss, a dádiva não seria "fundamentalmente diferente do mercado e do Estado"13. Quanto a este ponto, Mauss difere significativamente de Polanyi, de quem Godbout parece adotar uma tríade cara aos evolucionistas: dádiva, redistribuição e mercado. Sem chegar, entretanto, a negar a diferença entre a dívida mercantil e a dívida da dádiva, mostrarei a seguir que a redistribuição parece oferecer algo que, por falta de termo melhor, denominarei "forma geral" dos Estados ${ }^{14}$.

\section{SOCIEDADES MODERNAS}

$\mathrm{Na}$ "Conclusão" do Ensaio, Mauss estende suas observações para "as nossas sociedades". Para ele, como para Marx, estas se definem pelo papel central das relações de compra e venda. Ao

13 Conseqüentemente, discordo das afirmações de Godbout segundo as quais "o mercado e o estado são duas instituições neutras, que não alimentam nossas relações sociais", porque são "exteriores aos laços com as pessoas que nos são caras” (GODBOUT, 1998, p. 48).

14 Evito conscientemente a noção lévi-straussiana de "estrutura"; estamos aqui no nível da instituições e não de uma forma abstrata universal e intemporal. 
mesmo tempo, como para Lévi-Strauss (1952), o que Mauss denomina "nossas sociedades" também se define, de um ponto de vista quantitativo, pela multiplicação das relações de troca. Uma primeira conclusão: o estudo da circulação de riquezas, através da dádiva, oferece uma base para uma comparação inicial entre diferentes sociedades e permite uma passagem entre o estudo da nossa sociedade e o das "outras". Para Mauss, a dádiva, nas sociedades modernas, estaria "embutida na compra e venda", e não paralela ou independente desta. Mauss minimiza a importância das relações de "pura dádiva" no capitalismo, eximindo-se de uma análise de momentos como o do Natal, o das festas e das relações de hospitalidade na moderna civilização ocidental.

Nas suas referências à sociedade germânica, Mauss sugere ter ocorrido, nesta sociedade, um certo desenvolvimento histórico, da dádiva ao mercado. Mas a "Conclusão" do Ensaio nega a existência dessa linha contínua e da passagem supostamente universal. Mauss é ambígüo quanto a esse ponto: ora a presença do mercado enfraquece a dádiva, ora não, o mercado carregando a lógica da dádiva dentro de si. Em todo caso, sua posição na "Conclusão" deixa de ser aquela, claramente evolucionista, implícita no "Capítulo III", de que há um contínuo (lógico e histórico) da dádiva ao mercado. Mas, como vimos, mesmo no decorrer do "Capítulo III", em suas observações sobre a Índia antiga, Mauss indicava haver convivência entre dádiva e mercado.

Parece-me que, mais importante do que avaliar a incipiente presença do mercado nas "outras" civilizações, devemos considerar em profundidade a presença da dádiva na "nossa". Isto é, por mais que, como Marx e outros nos ensinaram, a sociedade ocidental moderna se caracterize por um desenvolvimento, sem precedentes na história humana, das relações mercantis, por outro lado Mauss (1974, p. 163) nos lembra que "não temos apenas uma moral de comerciantes". Não é apenas o hábito de presentear, oferecer hospitalidade ou dar festas que permanece entre nós, mas toda uma moral, derivada da intersubjetividade que estas relações implicam. Se, em determinados contextos, há conflito entre as lógicas da dádiva e da mercadoria, em outros pode haver complementaridade. Há instâncias onde cada uma dessas idéias opostas se verificam, a mercadoria ora pressupondo ora destruindo a dádiva (Lanna, 1995).
Mas na "Conclusão" do Ensaio Mauss não pensa em um paralelismo entre dádiva e mercadoria. Sua idéia, cuja importância, a meu ver, ainda não foi devidamente avaliada, é a de que, na modernidade, a dádiva está de certo modo embutida na compra e venda. Isto é, essas lógicas não se excluem porque "as coisas vendidas tem uma alma" (Mauss, 1974, p. 164). Neste momento do texto, Mauss faz uma defesa do socialismo. Haveria para ele um resquício da moralidade da dádiva no fato de os trabalhadores -, denominados por ele "produtores" -, terem "vontade de seguir a coisa que produziram" e "a sensação aguda de que seu trabalho é revendido sem que tomem parte no lucro". Mas Mauss assume algo, a meu ver, falso e não demonstrado em momento algum do Ensaio: que também os nativos das sociedades não capitalistas tenham esse "desejo" de seguir as dádivas que fazem. Os inúmeros exemplos etnográficos do Ensaio mostram exatamente o contrário, a saber:

a) que os desejos não organizam nem a produção nem a distribuição não capitalista;

b) que, ao contrário do que ocorre no capitalismo, a produção pode ser determinada pela troca;

c) que o fato de o doador "ir", ele mesmo, com as dádivas que faz - mesmo que ele não as tenha produzido, mas tenha sobre elas algum direito (é irmão da esposa do produtor, no caso do urigubu trobriandês, ou é o sobrinho uterino do produtor, no caso fijiano etc.) - é algo profundamente diferente do argumento psicologizante segundo o qual o trabalhador "quer seguir" as mercadorias que produz.

A sugestão da "Conclusão" do Ensaio é a de que o trabalho é sempre uma dádiva, em qualquer sociedade, capitalista (onde ele é também uma mercadoria) ou não. Essa tese segue a tradição da escola de Durkheim de se opor às análises de Marx da sociedade capitalista, pois, se verdadeira, implicaria a possibilidade de o operário ser ele mesmo o agente - simultaneamente voluntário e involuntário (dada a brilhante e indiscutível caracterização da dádiva pelo próprio Mauss) - da entrega de uma parte de si mesmo ao industrial. A posição marxista, quanto a isso, seria a de que semelhante entrega não deixa de ocorrer, mas não se trataria de dádiva e sim de algum tipo de apropriação, que talvez merecesse ser tida como 
extorsão.

Haveria, assim, conflito entre a posição marxista e a suposição, ao meu ver ingênua, de Mauss, de que a lógica da dádiva permite uma superação da alienação, no sentido de que, se pudesse o "produtor" elaborar mais o sentimento de que algo dele vai "com o bem dado", isso implicaria um maior "controle ou posse" sobre os bens, sobre si e sobre todo o processo social. Resta, entretanto, a intuição, a meu ver correta e que mereceria maiores estudos, de que há realmente um aspecto de dádiva na lógica da mercadoria, do trabalho e de suas representações nas sociedades capitalistas.

Mauss argumenta que artistas e operários seriam menos contaminados pela lógica burguesa da compra e venda. Por isso mesmo, Mauss deixa de aprofundar algumas de suas próprias reflexões sobre o fato de a burguesia (ele não usa o termo, mas a referência é clara) também praticar a dádiva (festas, hospitalidade, favores intra-patronais, etc.), o que poderia contradizer aquela tese. Seu argumento é no sentido de que a burguesia deveria se deixar contaminar mais profundamente por esta lógica universal que é a da dádiva. Já os operários, para Mauss, deveriam tomar maior consciência das próprias dádivas que fazem, de como suas vidas já são permeadas pela dádiva. Isto é, a esperança de Mauss era a de que a burguesia fosse cada vez menos individualista e os operários e artistas, cada vez mais. Estes não teriam consciência de sua posição para reivindicar, defender seus interesses. Assim se resolve a tensão, que mencionei acima, segundo a qual Mauss ora reconhece a presença da dádiva no capitalismo, ora nota sua ausência: seriam os operários os representantes da lógica da dádiva neste contexto.

Ora, foi exatamente nesse sentido que Mauss foi assimilado pela Antropologia urbana brasileira, ou ao menos pela paulista ${ }^{15}$. Meu argumento é de

15 Estudos como os de Sarti (1996), por exemplo, cometem o erro de associar a dádiva a uma "moral dos pobres", associando-se assim a uma tradição que trata os "pobres" como "outros" (CALDEIRA, 1984), dissociando trocas e ideologias de cada classe social e não analisando as trocas entre as classes. Ora, se a dádiva cria uma moral, isso também ocorre em nossa elite. Haveria ainda que se demonstrar até que ponto há uma "moral dos pobres" e uma "moral das elites" ou se não se trata de uma mesma que essa perspectiva é incompleta por não atentar para a capacidade burguesa de realização e de controle da dádiva, não atentar aos fatos, notados por T. Veblen (1953), que nos remetem ao "consumo conspícuo burguês". Este consumo ex-cludente a meu ver se generaliza na sociedade pós moderna, pois ele já não é mais prerrogativa dos proprietários dos meios de produção e caracteriza muito mais uma alta classe média "executiva". Isso do ponto de vista sociológico. Do ponto de vista dos valores, essa alta classe média de assalariados que dirigem as "sociedades anônimas" também "faz" a burguesia. Desenvolver essa tese seria perseguir um caminho já sugerido pelo próprio Marx quando demonstra, em $A$ ideologia alemã, que a burguesia tem a capacidade de generalizar seus valores, ainda que, evidentemente, não ao modo (hierárquico) dos brâmanes ou dos reis germânicos, analisados no Ensaio sobre a dádiva.

Ainda como para Marx, haveria, para Mauss, uma tendência "para a desumanidade" no desenvolvimento de "nossa sociedade". Mas a análise de Mauss não privilegia a esfera da economia, como Marx fez, mas sim o que ele denomina "códigos morais" e "o direito". Como para o também socialista K. Polanyi, para Mauss (1974, p. 165) um retorno a costumes antigos seria uma "reação sadia e boa", no sentido da superação de tendências do capitalismo. Mauss mostra que essas tendências poderiam ser consideradas nocivas segundo uma moral e um direito universais. Para Polanyi (1980), esta reação se concretizaria na importância crescente da lógica redistributiva. É claro que tanto Polanyi como Mauss não propõem uma volta a instituições do passado, mas sim a um "fundamento constante do direito, ao princípio mesmo da vida social moral" (MAUSS, 1974, p. 168). Esses seriam re-elaborados nas condições modernas, possibilitando que se acrescentasse "outros direitos ao direito brutal da compra e venda" para "limitar os frutos da especulação e da usura" (idem, p. 167).

A concepção de socialismo de Mauss implicaria então:

\footnotetext{
"moral". Mostrei como a dádiva é fundamento de sociabilidade tanto no engenho pernambucano como em um pequeno município potiguar, mas também como essa sociabilidade extende-se aos Poderes Legislativo e Executivo, ainda que essas morais não se baseiem apenas na lógica da dádiva (LANNA, 1995).
} 
1) a defesa dos mecanismos de legislação social e de redistribuição estatal, da importância da arrecadação de tributos (que, como tento argumentar alhures - Lanna 1995 -, não deixam de ser prestações totais, assemelhados assim às dádivas);

2) um pedido ingênuo para "os ricos" terem "boa-fé, sensibilidade e generosidade nos contratos de aluguel", ou "caridade, solidariedade", reconhecerem "o interesse que existe no dar" e o fato de que, se recebem dos trabalhadores bens e almas, que "voltem a considerar-se como espécies de tesoureiros de seus concidadãos"; apela-se inocentemente para que "os ricos" voltem às práticas de "despesa nobre" (MAUSS, 1974, p. 167). Note-se que há aqui uma visão aristocrática da burguesia enquanto classe dominante: ela é, de certo modo, associada aos chefes primitivos, enquanto beneficiários por excelência da dádiva. Mas, como para Marx, para Mauss "as massas" teriam "melhor que os dirigentes o sentido do interesse comum", enquanto os ricos teriam apenas o sentido do seu próprio interesse;

3) o argumento de que "os grupos devem agir", isto é, os sindicatos devem, enquanto associação voluntária, defender "seus interesses" (MAUSS, 1974, p. 168), devem participar do progresso, da lógica individualista. Da mesma forma, os artistas devem assumir seu direito à posse de suas criações, estas não sendo apenas dádivas, mas algo que pode ser vendido. Há uma defesa da arte; ela não perderia seu valor mágico se se tornasse, cada vez mais, também mercadoria ${ }^{16}$.

4) uma defesa da previdência privada e de que "o custo da segurança trabalhista fizesse parte das despesas gerais de cada indústria

\footnotetext{
16 Esse entendimento da arte como dádiva foi desenvolvido por Hyde (1979), que analisa, por exemplo, o "mito" da musa criadora. Permito-me aqui, muito modestamente, divergir de Mauss: o momento (pós-moderno?) quando a arte ocidental deixa se conceber como dádiva e se assume como mercadoria é aquele no qual ela se revoluciona de tal modo que praticamente deixa de existir (penso, por exemplo, no anúncio da morte da tradição musical ocidental, após Stravinsky, com o surgimento do dodecafonismo e da música concreta, feito por Lévi-Strauss na "Ouverture” das Mythologiques).
}

em particular" (idem, p. 166). Aliás, este argumento talvez fosse mais liberal do que socialista, mas se liga à percepção de que os trabalhadores merecem mais do que o salário.

Mauss enfatiza ainda que o estudo da dádiva importa também para a "gestão" da sociedade moderna. Essa gestão administrativa seria importante demais para se informar apenas pelo utilitarismo. Como Polanyi, Mauss indica a importância do estudo comparado das várias formas de economia e lamenta que os economistas pouco se dedicaram a essa questão, equivocando-se, aliás, quando tentaram (idem, p. 171). A meu ver, esse estudo se iniciaria com o reconhecimento da universalidade da noção de "valor" (com Dumont) e dos "signos de riqueza" (Saussure) e da especificidade da noção de valor mercantil (Marx).

Mauss (1974, p. 171) lembra que seu Ensaio segue a sugestão de Durkheim de uma origem religiosa da noção de valor econômico, já que nas sociedades não-capitalistas "as diversas atividades econômicas são impregnadas de ritos e mitos e guardam um caráter cerimonial obrigatório". Haveria, nessas atividades, um híbrido entre liberdade e obrigação, interesse e liberalidade. Mauss nos ensina a não associar o econômico à circulação do útil. Há "instituições econômicas", como "a divisão do trabalho", mesmo em "sociedades infinitamente menos evoluídas" (idem, p. 173). Mas, como nos ensina Dumont (1977), nem por isso devemos supor a inexistência de uma esfera da economia com um desenvolvimento caracteristicamente moderno: o mercado.

Critiquei aqui Mauss por adequar, de modo precipitado, "valores" não-capitalistas à "moeda" capitalista. Vimos ainda que, em outros momentos, Mauss (1974, p. 174) assimila rápido demais "o chefe trobriandês ou tsimshian" ao "capitalista". Vimos que, se valores, como os cobres do potlatch, são "signos de riqueza e meios de troca" (ibidem), eles, ao contrário do dinheiro capitalista, circulam em esferas. Ao contrário do dinheiro, seu valor não se generaliza da mesma maneira. Um vaygu'a (colares ou braceletes kula) é um valor supremo não enquanto valor econômico, pois não pode ser trocado por quaisquer outras mercadorias; o que se generaliza é seu significado hierárquico, religioso inclusive, dada sua imersão específica no conjunto da gramática da sociedade trobriandesa. Quanto à questão dos valores em relação, aliás, 
Saussure é evidentemente mais sofisticado que seu contemporâneo Mauss.

Outro tema fundamental do Ensaio é a indicação de que as noções de interesse e de utilidade assumem significados específicos em cada caso concreto $^{17}$ e de que na nossa sociedade o interesse assume uma forma "pura"; surge daí a transformação do homem em um "animal econômico" (idem, p. 176). A noção de interesse seria "uma categoria da ação" (ibidem); por isso mesmo, "não será no cálculo das necessidades individuais que se encontrará o método da melhor economia" (idem, p. 177). A análise econômica não pode se limitar apenas à "nossa sociedade", sob o risco de generalizar noções particulares, como as de "necessidade" e "interesse individual". Neste caso, ela incentivará "a perseguição brutal dos fins do indivíduo [que, ao contrário do que postulam os teóricos liberais] é nociva aos fins e à paz do conjunto" (ibidem).

Mauss conclui o Ensaio fazendo um elogio do estudo do concreto. A teoria comparada, econômica ou não, deve antes de mais nada iniciar-se pela etnografia. Nada seria mais urgente e frutífero do que encontrar fatos novos para enriquecer o estudo comparativo. A etnografia desvendaria a cor local de algo universal, a moral da dádiva. Os sociólogos deveriam, como os historiadores e psicólogos, deixar de fazer "abstrações em demasia" (idem, p. 181).

Finalmente, Mauss argumenta que a dádiva implicaria mais felicidade e menos seriedade (idem, p. 182). O caminho a seguir seria ainda o de trocar mais e guerrear menos. Se, em certos momentos, a sociedade ocidental se afastou da dádiva, Mauss não pensa este afastamento como definitivo. Como posteriormente fez Lévi-Strauss (1952), Mauss (1974, p. 183) não deixa de associar a intensificação das trocas à noção de progresso. O progresso, assim como o crescente aumento das diferenças sociais, se explicaria pela intensificação das trocas. Mas se Mauss pensa em um efeito deletério das trocas mercantis, Lévi-Strauss pensa em efeito deletério da intensificação de qualquer

17 Esta é uma conclusão que só muito recentemente foi assimilada pela Antropologia anglo-saxã (cf. PARRY \& BLOCH, 1989). tipo de troca. Quanto a isso, Lévi-Strauss (1952, 1998, entre outros) é também mais explícito, argumentando inclusive a favor de um "esfriamento" da história do Ocidente. Esta "máquina a vapor" deveria aprender com as "sociedades frias" a ser menos obstinada, a desejar menos as inovações - que ele mesmo, como Karl Marx já o fizera, mostrou ser o oxigênio da "civilização mecânica".

Mauss, por sua vez, na "Conclusão" do Ensaio, argumenta a favor de uma intensificação das trocas de dádivas, que para ele conduziria, ao contrário do que para Lévi-Strauss, a uma minimização da estratificação entre nações e indivíduos, esta sendo o resultado da intensificação (apenas) das trocas mercantis. Se o Ensaio mostra como a dádiva "estabelece a hierarquia", Mauss (1974, p. 174) não deixa de reconhecer haver outros modos de produção da diferença social: a dádiva "não seria absolutamente necessária para tanto".

Está implícita no Ensaio a suposição de que a diferença estabelecida na troca de dádivas nos salvaria da constante criação de diferenças estabelecida pela troca mercantil. Nesse sentido, o paralelo entre Mauss e Marx é evidente: para este, o capitalismo se autodestruiria, e seria sucedido por uma sociedade mais igualitária. Para Mauss, trata-se menos de substituir as formas capitalistas de produção de desigualdades e muito mais de se estimular a produção de desigualdades a partir da dádiva, de tal forma que estas se sobrepusessem gradualmente àquelas.

Se Mauss é, de certo modo, mais pessimista que Marx, Lévi-Strauss o é ainda mais que ambos: para o último, quanto mais troca, seja ela de qual tipo for, mais exploração. Finalmente, penso ser importantíssimo lembrar que, em sua "Conclusão" otimista, Mauss nega uma das demonstrações de seu próprio Ensaio, a de que a solidariedade gerada pela dádiva não pode ser sem sacrifício. Isto é, essa troca de dádivas não exclui o interesse, não exclui (mas a meu ver pressupõe) a produção de desigualdades e mais ainda, de sofrimento humano. Mas, ao fim e ao cabo, o tom otimista da "Conclusão" parece se justificar minimamente pelo fato de Mauss nos ensinar algo, a meu ver, absolutamente funda-mental: a felicidade humana não está em outra parte que não no dar e receber, "no respeito mútuo e na generosidade recíproca".

Recebido para publicação em 11 de março de 1999. 
Marcos Lanna (mlanna@ coruja.humanas.ufpr.br) é Professor Adjunto do Departamento de Antropologia da Universidade Federal do Paraná (UFPR).

\section{REFERÊNCIAS BIBLIOGRÁFICAS}

BARRAUD, C., De COPPET, D., ITEANU, A. \& JAMOUS, R. 1984. Des relations et des morts; quatre sociétés vues sous l'angles des échanges. In : GALEY, J.-C. (org.). Différences, valeurs, hiérarchie. Textes offerts à L. Dumont. Paris : EHESS.

BLOCH, M. \& PARRY, J. (eds.). 1989. Money and the morality of exchange.Cambridge : Cambridge University Press.

BOURDIEU, P. 1996. Marginália. Algumas notas adicionais sobre o dom. Mana, Rio de Janeiro, v. 2 , n. 2, p. 7-20.

CAILLÉ, A. 1998. Nem holismo nem individualismo metodológicos. Marcel Mauss e o paradigma da dádiva. Revista Brasileira de Ciências Sociais, São Paulo, v. 13, n. 38, out.

CALDEIRA, T. 1984. A política dos outros : o cotidiano dos moradores da periferia e o que pensam do poder e dos poderosos. São Paulo : Brasiliense.

CARNEIRO DA CUNHA, M. \& VIVEIROS DE CASTRO, E. 1985. Vingança e temporalidade : os Tupinambá. Journal de la Societé des Américanistes, n. LXXI, p. 191-208.

CLASTRES, P. 1978. A sociedade contra o Estado.Pesquisas de Antropologia Política. Rio de Janeiro : Francisco Alves.

LUCENA, E. 1999. Por um punhado de dólares. Folha de São Paulo, 7 de março, p. E4.

DUMONT, L. 1971. Introduction à deux théories d'anthropologie sociale : groupes de filiation et alliance de mariage. La Haye-Paris : Mouton.

1977. Homo aequalis. Genèse et épanouissement de l'idéologie économique. Paris : Gallimard. Rocco.

1986. O individualismo. Rio de Janeiro :

1992[1966]. Homo hierarchicus. O sistema de castas e suas implicações. São Paulo : Edusp.
FOURNIER, M. 1993. Marcel Mauss ou a dádiva de si. Revista Brasileira de Ciências Sociais, São Paulo, n. 21, p. 104-112, fev.

GIANNOTTI, J. A. 1983. Trabalho e reflexão. São Paulo : Brasiliense.

GODBOUT, J. T. 1998. Introdução à dádiva. Revista Brasileira de Ciências Sociais, São Paulo, v. 13, n. 38, outubro, p. 39-51.

GODELIER, M. 1981. Coleção "Os grandes cientistas sociais”, n. 21. São Paulo : Ática.

GODELIER, M., TRAUTMAN, T. \& TJON SIE FAT, F. E. (eds.). 1998. Transformations of kinship. Washington/London : Smithsonian Institution Press.

GOMES JR. 1999. A etnografia como gênero literário. Folha de S.Paulo, Jornal de Resenhas. 13 de fevereiro.

GOODY, J. 1973. Bridewealth and dowry in Africa and Eurásia. In : GOODY, J. \& TAMBIAH, S. Bridewealth and dowry. Cambridge : Cambridge University Press.

. 1983. The Development of the family and marriage in Europe. Cambridge : Cambridge University Press.

GUIDIERI, R. 1984. L'abondance des pauvres.Paris : Seuil.

HYDE, L. 1979. The gift. New York : Vintage Books.

JAMIN, J. 1992. Marcel Mauss. In : BONTE, P. \& IZARD, M. Dictionnaire de l'Ethnologie et de l'Anthropologie. Paris : PUF.

LANNA, M. 1992. Repensando a troca trobriandesa. Revista de Antropologia, São Paulo, n. 35, p. 129-148.

1995. A Divida divina. Troca e patronagem no nordeste brasileiro. Campinas : Unicamp.

1996. Reciprocidade e hierarquia. Revista de Antropologia, São Paulo, v. 39, n. 1, p. 111144.

. 1998. Apresentando Raymond Firth. In : 
FIRTH, R. Nós, os tikopias. São Paulo : Edusp. (1999). Sobre a comunicação entre diferentes Antropologias. Revista de Antropologia, São Paulo, número especial dedicado à obra de C. Lévi-Strauss, vol. 42, n. 1 e 2.

LEFORT, C. 1979. As formas da história. São Paulo : Brasiliense.

LÉVI-STRAUSS, C. 1944. La sociologie française. In : GURVITCH, G. (ed.). $L a$ Sociologie au XX' $X^{\text {eme }}$ siècle. Paris : PUF.

1949. Les structures élémentaires de la parenté. Paris : PUF.

1952. Papai Noel supliciado. Anhembi, São Paulo, v. VI, n. 16, p. 12-26. Plon.

1958. Anthropologie structurale. Paris :

1974[1950]. A obra de Marcel Mauss. In :

MAUSS, M. Sociologia e Antropologia. São Paulo : Edusp.

1979. A via das máscaras. Lisboa : Presença.

1992. Franz Boas. In : Dictionnaire de l'Ethnologie et de l'Anthropologie. Paris : PUF.

1998. A Antropologia de cabeça para baixo. Entrevista a E. Viveiros de Castro. Mana, Rio de Janeiro, v. 4, n. 2, p. 119-126.

MAUSS, M. 1974 [1923-24]. Ensaio sobre a dádiva. Forma e razão da troca nas sociedades arcaicas. In : Sociologia e Antropologia. v. II. São Paulo : Edusp.

1983. An intelectual self-portrait. In : BESNARD, P. (ed.) The sociological domain. Mimeo.
MUNN, N. 1986. The fame of Gawa. Cambridge : Cambridge University Press.

DELFIM NETTO, A. 1999. Ética e economia. Folha de S.Paulo, 3 de março, p. A2.

POLANYI, K. 1980 [1944]. A grande transformação. As origens de nossa época. Rio de Janeiro : Campus.

SAHLINS, M. 1976. Culture and practical reason. Chicago : The University of Chicago Press.

1988. Cosmologies of capitalism : the trans-Pacific sector of the World System. Proceedings of the British Academy, London, LXXIV, p. 1-51.

SAPIR, E. 1994. The Psychology of culture. A course of lectures. Berlin/New York : Mouton/Gruyter.

SARTI, C. 1996. A família como espelho. Campinas : Autores Associados.

VEBLEN, T. 1953[1899]. The theory of the leisure class. New York : Mentor/Vicking/ Macmillan.

VIVEIROS DE CASTRO, E. 1996. Images of nature and society in Amazonian ethnology. Annual Review of Anthropology, v. 25, p. 179200.

1998. A Antropologia de cabeça para baixo. Entrevista com C. Lévi-Strauss. Mana, Rio de Janeiro, v. 4, n. 2, p. 119-126.

WEINER, A. 1976. Women of value, men of renown. Austin : University of Texas Press.

1992. Inalienable possessions. The paradox of keeping while giving. Berkeley : The University of California Press. 